\title{
Raman detection of hydrohalite formation: Avoiding accidents on icy roads by deicing
} where salt will not work

\section{Berg, Rolf W.}

Published in:

Applied Spectroscopy Reviews

Link to article, DOI:

10.1080/05704928.2017.1396540

Publication date:

2017

Document Version

Peer reviewed version

Link back to DTU Orbit

Citation (APA):

Berg, R. W. (2017). Raman detection of hydrohalite formation: Avoiding accidents on icy roads by deicing where salt will not work. Applied Spectroscopy Reviews, 53(6), 503-515.

https://doi.org/10.1080/05704928.2017.1396540

\section{General rights}

Copyright and moral rights for the publications made accessible in the public portal are retained by the authors and/or other copyright owners and it is a condition of accessing publications that users recognise and abide by the legal requirements associated with these rights.

- Users may download and print one copy of any publication from the public portal for the purpose of private study or research.

- You may not further distribute the material or use it for any profit-making activity or commercial gain

- You may freely distribute the URL identifying the publication in the public portal

If you believe that this document breaches copyright please contact us providing details, and we will remove access to the work immediately and investigate your claim 
R. W. Berg: Hydrohalite, Raman and safe traffic

Document 283 Name: ASR-Document 19-10-2017.docx

\title{
Title: Raman Detection of Hydrohalite Formation. Avoiding Accidents on Icy Roads by Deicing where Salt will not work
}

35 sign header:

Hydrohalite, Raman and safe traffic

\author{
By: Rolf W. Berg \\ Department of Chemistry, Technical University of Denmark \\ DTU Kemi, Kemitorvet 207, DK-2800 Kgs. Lyngby, Denmark \\ Email: rwb@kemi.dtu.dk
}

Color versions of one or more figures in this article are available online at www.tandfonline.com/laps.

\begin{abstract}
The common substance Hydrohalite has a role to play in as diverse areas as Geology, Earth Climatology, Universe Cosmology and Cryobiology. In this review the occurrences under very different occasions are described. These relations are not commonly appreciated. During the work we realized that there is yet an aspect that has been overlooked. Hydrohalite formed sometimes on icy roads resists common salt deicing procedures. Also hydrohalite can be detected by rather simple Raman spectroscopy instrumentation. It means that it is possible to avoid accidents on icy roads in the following way: Common salt deicing trucks may be equipped with "artificial intelligence" based on a duel deicing system that switches between normal $\mathrm{NaCl}$ deicing and non- $\mathrm{NaCl}$ deicing based on Raman spectroscopy. The advantages are first of all less traffic accidents and lower environmental impact and corrosion from $\mathrm{NaCl}$, but disadvantages are increased costs of investments and consumption of non- $\mathrm{NaCl}$ deicing agents.
\end{abstract}


R. W. Berg: Hydrohalite, Raman and safe traffic

\section{Keywords}

Raman Spectroscopy, $\mathrm{NaCl}$-Dihydrate, $\mathrm{NaCl} \cdot 2 \mathrm{H}_{2} \mathrm{O}$, Hydrohalite, Slippery Roads, Road DeIcing, Traffic Accidents

Date received: 19 October 2017

\section{Introduction}

This manuscript reports a Raman spectroscopy literature review on hydrohalite (sodium chloride dihydrate: $\mathrm{NaCl} \cdot 2 \mathrm{H}_{2} \mathrm{O}$ ) and its existence in relation to geology, earth's climate, cosmology, and cryobiology. The hope was to let these fields - seeming far removed from each other - appreciate their common interests. An included Raman study of mixtures of sodium chloride and water at low temperature confirmed that the spectra contain specific features that allow detection of solid hydrohalite formation. The interest in hydrohalite formation came from the common knowledge that ice layers on roads are jeopardizing because the friction needed for safe traffic is lost. In addition, it is may be observed that the commonly used de-icing procedure of spreading salt on slippery road pavements does not always work. Formation of hydrohalite is a likely reason for "ice-look-alike" precipitates not to melt despite de-icing with salt. Accordingly, we set out to search for a new kind of de-icing system as illustrated in Figure 1.

\section{Theory}

The reason for $\mathrm{NaCl}$ to make ice melt is that the corresponding saline solution (brine) has a lower freeing point than water. The salt depresses the freezing point. This freezing point depression principle often works fine. However, cases are known in which the salting 
R. W. Berg: $\quad$ Hydrohalite, Raman and safe traffic

doesn't help, no matter how much salt is added. One reason could be that the temperature is too low, below about $-21^{\circ} \mathrm{C}$, but the most common cause - often unnoticed - is the formation of hydrohalite (sodium chloride dihydrate: $\mathrm{NaCl} \cdot 2 \mathrm{H}_{2} \mathrm{O}$ ). This solid salt, containing $61.86 \% \mathrm{NaCl}$ by weight, has an incongruent melting point of about $+0.11^{\circ} \mathrm{C}$. It is thermodynamically stable below that temperature and can coexist with ice or concentrated brine, as it is seen from the binary $\mathrm{NaCl}-\mathrm{H}_{2} \mathrm{O}$ phase system shown in Figure 2 [1]-[12]. The hydrohalite crystals often look like thin hexagon plates that adopt a known monoclinic crystal structure containing hydrogen bonds between $\mathrm{O}$ and $\mathrm{Cl}[13]-[15]$. The microphysics of the formation of ice and hydrohalite in aqueous $\mathrm{NaCl}$ has been studied by differential scanning calorimetry and flow cell microscopy for various conditions, such as the concentration during deliquescence and efflorence [17].

During freezing out of ice on wet salted roads, the remaining liquid becomes more and more concentrated in $\mathrm{NaCl}$ because the ice itself has a low solubility of solid salts. The freezing point of the liquid drops along the ice liquidus curve in the phase diagram (Figure 2), from the normal freezing point of pure water $\left(0\right.$ weight $\left.\% \mathrm{NaCl}, 0{ }^{\circ} \mathrm{C}\right)$ down to the eutectic point $\left(\sim 23\right.$ weight $\left.\% \mathrm{NaCl}, \sim-21^{\circ} \mathrm{C}\right)$. The ice liquidus (red curve) has been carefully expressed by equations of the freezing point versus the salt concentration [5], [7], [16], [18]-[17]. During continued cooling below the eutectic point the hydrated salt, $\mathrm{NaCl} \cdot 2 \mathrm{H}_{2} \mathrm{O}$, precipitates along with ice. Often an equilibrium situation will be established during freezing of the eutectic solution forming the hydrated salt / solid ice mixture but sub cooling may also occur. At temperatures below the eutectic one, the liquid phase should disappear and only ice and $\mathrm{NaCl} \cdot 2 \mathrm{H}_{2} \mathrm{O}$ left.

Alternatively, when highly concentrated salt solutions with of more than $\sim 21 \% \mathrm{NaCl}$ by weight are frozen, hydrohalite crystals $(61.86 \% \mathrm{NaCl})$ tend to form directly, at temperatures 
R. W. Berg: $\quad$ Hydrohalite, Raman and safe traffic

depending on the salt concentration, and the remaining solution follows the hydrohalite liquidus curve, see Figure 2 (blue curve). For e.g. a 25 weight \% $\mathrm{NaCl}$ solution the hydrohalite starts to freeze out below about $-6^{\circ} \mathrm{C}$. The crystal formation is often kinetically inhibited [1] but it can be promoted by e.g. temperature cycling or addition of seeding agents like alumina powder [19]. The hydrohalite liquidus curve ends at the peritectic point ( 26.3 weight $\% \mathrm{NaCl}, \sim 0.1^{\circ} \mathrm{C}$ ), at above which temperature the hydrate melts incongruently to form $\mathrm{NaCl}$ (halite) and a $\mathrm{NaCl}$-saturated solution. According to Figure 2, stable hydrohalite only exists at temperatures below $+0.1^{\circ} \mathrm{C}$.

The interesting question of why ice is slippery has been long studied [22]. The belief is that the loss of friction can be explained as due to a dynamically formation of a thin film of liquid water at the ice surface as the result of a freezing point depression due to the pressure, such as seen e.g. during ice-skating and under the wheels of the traffic [22].

Hydrohalite often remains unnoticed because of its superficial resemblance to road ice or when dark - even the pavement. In the microscope, clear and colorless hydrohalite crystals are readily recognized from ice or salt by their monoclinic prism morphology, somewhat reminiscent of gypsum. Super saturation is essential to the $\mathrm{NaCl} \cdot 2 \mathrm{H}_{2} \mathrm{O}$ phase formation, thus explaining why it many times is not precipitated although it ought to. This was why the question of hydrohalite detection came up. In our university, Thomsen et al. [20]-[21] suggested that Raman spectroscopy could be a method to detect the formation and presence of hydrohalite, and accordingly we performed a literature search and did the experiments reported here in order to find out if detection can indeed be done. The harm and expenses involved in traffic accidents make it worth trying to develop any means to detect and avoid dangerous road situations, so that the traffic can be warned. 
R. W. Berg: $\quad$ Hydrohalite, Raman and safe traffic

The main object of this work is thus to devise a possibility to detect hydrohalite. The traffic authorities could then be put in an alert situation in such a case, warnings could be send out, one could stop useless salt spreading and shift to a deicing procedure based on something else than $\mathrm{NaCl}$.

At first we look on the Raman spectra of hydrohalite and then we look on alternative deicers.

\section{Literature on Raman spectra and Formation of Hydrohalite}

The Raman spectrum of $\mathrm{NaCl} \cdot 2 \mathrm{H}_{2} \mathrm{O}$ has been found of interest in several fields of research:

Geology: Hydrohalite has been detected directly as a mineral, e.g. on Antarctica where several hyper-saline ice-covered lakes exist in which hydrohalite persists permanently; also in many temperate lakes hydrohalite crystals are formed on an annual (winter) basis [23]. Although the constituents of hydrohalite are nearly ubiquitous on Earth's surface, the compound is rarely described as a mineral because it forms and persists only at temperatures below $0{ }^{\circ} \mathrm{C}$ and disappears when melting. In searches of valuable minerals, oil and gasses, geologists often find compounds in mineral fluid inclusions and studied their contents extensively under extreme conditions, see e.g. [2]-[3], [11], [24]. Cooled natural or synthetic droplets have been studied under the microscope at low temperatures, and Raman spectra have been obtained from ice and many solid salt hydrates [19], [25]-[32]. In these studies laser beams were typically focused within the inclusions in mineral slices resting on heating/cooling microscope stages, associated with confocal optical arrangements to enable Raman spectroscopy at controlled temperatures. Spectra at selected temperatures were analyzed for peak positions that compare with already compiled data for the most common 
R. W. Berg: $\quad$ Hydrohalite, Raman and safe traffic

substances. Ice and hydrohalite were repeatedly identified within such inclusions and some of the literature results are reproduced in Table 1.

Earth Climate: Crystalline sodium chloride particles are formed when air parcels containing droplets of aqueous $\mathrm{NaCl}$ solution (sea mist) are exposed to dry air (relative humidity below 38-44\%). Such situations are common in the atmosphere. Crystalline hydrated sodium chloride particles, $\mathrm{NaCl} \cdot 2 \mathrm{H}_{2} \mathrm{O}$, may form at high altitudes and low temperatures; and such particles have proved to be remarkably efficient nuclei for ice formation in the troposphere. Accordingly, upon drying out and efflorescence, two kinds of crystalline species have shown tendencies to form up there, namely anhydrous $\mathrm{NaCl}$ and dihydrate $\mathrm{NaCl} \cdot 2 \mathrm{H}_{2} \mathrm{O}$, and these compounds thus exert strong influence on the Earth climate [33]-[34]. Raman spectroscopy was used to detect the formation of crystalline $\mathrm{NaCl} \cdot 2 \mathrm{H}_{2} \mathrm{O}$ under simulated atmospheric conditions [33]. Small $\mathrm{NaCl}(\mathrm{s})$ particles (about $5 \mu \mathrm{m}$ in diameter) were found to deliquesce at high relative humidity, and homogeneous crystallization at low temperatures often only leads to the formation of the anhydrous salt phase. At low temperatures, between -37 and $-21{ }^{\circ} \mathrm{C}$, drops of $\mathrm{NaCl}(\mathrm{aq})$ effloresce to a mixture of hydrated and non-hydrated particles, because nucleation of the stable hydrohalite apparently is difficult, if not triggered by heterogeneous crystallization on suitable surfaces. At temperatures warmer than $-21^{\circ} \mathrm{C}$ the aqueous particles were found to effloresce into the non-hydrated form, but at temperatures colder than $-37^{\circ} \mathrm{C}$ all particles apparently effloresced into $\mathrm{NaCl} \cdot 2 \mathrm{H}_{2} \mathrm{O}$. To reach that conclusion it was necessary to take into account that the Raman spectra of $\mathrm{NaCl} \cdot 2 \mathrm{H}_{2} \mathrm{O}$ show noticeable variations versus the temperature at which the spectra were collected [33]-[34]. Spectra of $\mathrm{NaCl} \cdot 2 \mathrm{H}_{2} \mathrm{O}$ show sharp intense bands at about $3530 \mathrm{~cm}^{-1}$ and $3410 \mathrm{~cm}^{-1}$, whereas the $\mathrm{NaCl}$ particles or drops of solution differed markedly because $\mathrm{NaCl}(\mathrm{s})$ shows no Raman features at all, and water has only weak and broad Raman bands. 
R. W. Berg: $\quad$ Hydrohalite, Raman and safe traffic

Cosmology: In the solar system binary $\mathrm{H}_{2} \mathrm{O}+\mathrm{NaCl}$ aqueous electrolyte systems have attracted considerable interest after the discovery of many large icy objects like comets and moons [35]. For example, the sixth-closest moon, Europa, orbiting around the planet Jupiter, has an estimated $9 \mathrm{~km}$ thick icy shell overlying an aqueous liquid mantle covering a salty subsurface ocean. This icy cover, and perhaps the liquid underneath and bottom deposits are estimated to contain gigantic amounts of hydrohalite [12], [36]. However, the current knowledge of Europa's subsurface ocean is sparse, and its eventual habitability is critically depending on e.g. its composition. Therefore, intensive research is ongoing to examine the chemistry and materials composition of Europa's surface and subsurface ocean. Hence, earthy laboratory model experiments have been made on microliter droplets of solutions placed between glass microscope slides, in addition to confocal dispersive Raman spectroscopy performed at cryogenic conditions, using also temperature cycling and annealing to simulate real situations. Raman spectra of hydrohalite were again found to depend much on temperature and pressure (in diamond anvil cells up to high pressures), typically showing two very distinct bands in the O-H stretching region at around 3536-3540 and $3420 \mathrm{~cm}^{-1}$ [12], [36]. The latter strong band exhibited shoulders at about 3403-3405 and $3435 \mathrm{~cm}^{-1}$, in good agreement with spectra reported by other researchers [25]-[27], [32].

Cryobiology: Indications of formation of hydrohalite (and perhaps other salt hydrates) have been detected in samples of cryopreserved biological cultures and frozen human cells by virtue of their unique Raman spectra [37]-[40]. The unambiguous identification was claimed to be possible because hydrohalite has several characteristic high frequency $\mathrm{OH}$ stretching bands allowing for its identification. The $\mathrm{OH}$ stretching band of liquid water was found to be broad $\left(3000-3600 \mathrm{~cm}^{-1}\right)$ and asymmetric, with its peak maximum located at about $3420 \mathrm{~cm}^{-}$ 1, whereas hydrohalite had narrow signatures in the $\mathrm{OH}$ stretching band envelope, apparently distinct because water molecules are bound in specific configurations. The 
R. W. Berg: $\quad$ Hydrohalite, Raman and safe traffic

hydrohalite spectrum was described as mostly consisting of two distinct bands near 3400 $\mathrm{cm}^{-1}$ and $3520 \mathrm{~cm}^{-1}$, and the relative strength of these bands was found to depend on the orientation of the hydrohalite crystals in relation to the polarization of the laser, and this fact could be used to differentiate between hydrohalite crystals having different orientations [38][39].

\section{Experimental}

$\mathrm{NaCl} \cdot 2 \mathrm{H}_{2} \mathrm{O}$ crystals were made by cooling supersaturated pure water solutions of $\mathrm{NaCl}$ (CAS \#7647-14-5 from Sigma-Aldrich, TraceSELECT ${ }^{\circledR} \geq 99.999 \%$ metals basis) in small beakers of stainless steel. Several solutions were frozen at low temperatures (below $-22^{\circ} \mathrm{C}$ in a deep freezer or by means of liquid nitrogen). The crystals (1-3 mm thick hexagon plates) looked like ice but had a more greasy appearance. In most cases mixtures of ice, $\mathrm{NaCl}$ and $\mathrm{NaCl} \cdot 2 \mathrm{H}_{2} \mathrm{O}$ crystals were obtained rather independent of temperature history.

The frozen solids were used directly for obtaining Raman spectra. Stationary Raman setups were used consisting of DILOR-XY or Renishaw-inVia Spectrometers with standard or UVenhanced Suprasil $^{\mathrm{TM}}$ quartz optics, microscopes, highly sensitive cooled CCD detectors and other necessary accessories described in [41]-[43]. Excitation was done with light from doubled $\mathrm{Nd}^{3+}$ solid state and $\mathrm{Ar}^{+}$gas lasers operating at $\sim 532,514.5$ and $488.0 \mathrm{~nm}$. The slit widths were set to $\sim 300$ and $\sim 65 \mu \mathrm{m}$.

A portable ( $5 \mathrm{~kg})$ i-Raman Plus BWS465-532S spectrometer system from B\&WTEK was also used [44]. It contained a $532 \mathrm{~nm}$ laser source $(\sim 40 \mathrm{~mW})$ that excited the samples through a fiber optic probe with band pass and notch filters. The back scattered Raman light 
R. W. Berg: $\quad$ Hydrohalite, Raman and safe traffic

was resolved in a fixed grating spectrometer applying focusing on a CCD with 2048 detector elements cooled to $-2{ }^{\circ} \mathrm{C}$. The spectral resolution was at around $5 \mathrm{~cm}^{-1}$ allowing for a Stokes spectral coverage from $\sim 175$ to $\sim 4200 \mathrm{~cm}^{-1}$. A repeated integration time of $60 \mathrm{~s}$ was used and the background was subtracted with the help of the BWSpec ${ }^{\circledR}$ software [44].

\section{Results and Discussion}

We prepared samples of ordinary ice and $\mathrm{NaCl} \cdot 2 \mathrm{H}_{2} \mathrm{O}$. As expected, the ice was found to melt when cold salt was added, but the $\mathrm{NaCl} \cdot 2 \mathrm{H}_{2} \mathrm{O}$ did not melt with addition of cold salt. Raman spectra were measured in the temperature range below $0{ }^{\circ} \mathrm{C}$ and down to $-26{ }^{\circ} \mathrm{C}$, then during temperature cycling up and down and finally down to $-196^{\circ} \mathrm{C}$. Spectra are given for water/ice in Figure 3 and for saturated brine/hydrohalite in Figure 4.

As mentioned previously ice and salt hydrates in general are known to possess characteristic spectra. Naturally, ice itself has been studied many times, in many phases and under many different conditions. The ice spectra will not be discussed here, but we note that our spectra - in Figure 3 - are looking like those previously reported. Typical literature spectra of ice are found e.g. in references [26]-[29], [32]-[33], [36], [38]-[40], [45]-[49]. We note that the ice peaks at positions around $3080-3160 \mathrm{~cm}^{-1}$ are depending on the temperature history of the sample.

Initial attempts to obtain hydrohalite spectra are shown in Figure 4. The spectrum of the liquid brine differs somewhat from that of pure water; the broad bands of the water are shifted as reported previously, see e.g. reference [27], [49]. During the cooling/cycling below $0{ }^{\circ} \mathrm{C}$ new bands are coming up, originating from hydrohalite mixed with ice. By use of seeding 
R. W. Berg: $\quad$ Hydrohalite, Raman and safe traffic

with previously made hydrohalite crystals we succeeded in making large pure crystals of hydrohalite without any Raman evidence of ice (compare Figures 4 and 5).

There has been some discussion in the literature [25]-[36] about which bands really belong to the hydrohalite phase. Wise et al. [33] have convincingly shown (in their Figures 7a and 7b [33]) that Raman bands at around $\sim 3100$ and $\sim 3160 \mathrm{~cm}^{-1}$ come from ice nucleated on hydrohalite particles, because these bands disappeared after the ice had disappeared by sublimation, whereas the other bands - due to hydrohalite - remained. This must mean that the vanishing bands are due to the ice that apparently sublimes better than hydrohalite. We have in our spectra (Figure 5) observed the same spectral results: no bands were seen in the range at about $3100-3200 \mathrm{~cm}^{-1}$. It therefore must be concluded that bands often referred to as hydrohalite at around $\sim 3100$ to $\sim 3160 \mathrm{~cm}^{-1}$ should be explained as due to a simultaneous occurrence of crystalline ice and hydrohalite. The hydrohalite Raman transitions are summarized in Table 1. It should be mentioned that hydrohalite may adopt different polymorphs, some of which may even have bands below $3200 \mathrm{~cm}^{-1}$, as suggested by some authors [12], [30].

The two most characteristic strong hydrohalite bands are found at $\sim 3425 \mathrm{~cm}^{-1}$ and $\sim 3550$ $\mathrm{cm}^{-1}$ (in Figure 4 and 5). These $\mathrm{NaCl} \cdot 2 \mathrm{H}_{2} \mathrm{O}$ bands have been reported in all of the relevant literature above (see Table 1), most clearly seen at low temperatures $\left(<-100^{\circ} \mathrm{C}\right)$, where the hydrohalite Raman bands are narrow and where also the small peaks can be distinguished when the resolution is high enough.

To estimate how many vibrational bands could arise from hydrohalite, knowlegde of the crystal structure is required. The $\mathrm{NaCl} \cdot 2 \mathrm{H}_{2} \mathrm{O}$ phase is monoclinic, crystallizing in space group P2 $1 / c$ with $a=6.331 \AA, b=10.118 \AA, c=6.503 \AA, \beta=114.4^{\circ}, Z=4$, and density $=$ 
R. W. Berg: $\quad$ Hydrohalite, Raman and safe traffic

$1.61 \mathrm{~g} / \mathrm{cm}^{3}$ [13]-[14]. The eight specific water molecules (four formula units of each $2 \mathrm{H}_{2} \mathrm{O}$ ) in the primitive cell (not just 2 as claimed [21]) form the basis of the prediction. The transitions between the internal vibrational levels of these 8 water molecules would give $8 \times 2=16 \mathrm{OH}$ stretching fundamentals and $8 \mathrm{H}_{2} \mathrm{O}$ bendings. Many of these transitions obviously occur at the same frequencies (degenerate bands).

The relative amplitudes between the $\mathrm{O}-\mathrm{H}$ stretching bands at $\sim 3425 \mathrm{~cm}^{-1}$ and $\sim 3550 \mathrm{~cm}^{-1}$ bands have been found to depend on the orientation of the hydrohalite crystals. We did not study differently orientated hydrohalite crystals but we note that the variation in the relative peak intensities could be explained as consequence of different crystal orientations relative to the polarization of the laser light as discussed in [38]-[39]. Also we note that the positions of the peaks are quite dependent on the temperature [27], [32].

In addition to the $\mathrm{O}-\mathrm{H}$ stretching bands above $3000 \mathrm{~cm}^{-1}$, water molecule bending mode bands are expected to occur below $1700 \mathrm{~cm}^{-1}$ with relatively low intensity. The $8 \mathrm{H}_{2} \mathrm{O}$ molecules in the unit cell in practice give rise to the two $\mathrm{HOH}$ angle bending bands seen at 1646 and $1665 \mathrm{~cm}^{-1}$ (Table 1). 
R. W. Berg:

Hydrohalite, Raman and safe traffic

Table 1. Raman peaks of ice and hydrohalite $\left(\mathrm{cm}^{-1}\right)$ at $-20{ }^{\circ} \mathrm{C}$ and $-180{ }^{\circ} \mathrm{C}$

\begin{tabular}{|c|c|c|c|c|}
\hline Phase & $\begin{array}{l}\text { This work, } \\
-20{ }^{\circ} \mathrm{C}\end{array}$ & $\begin{array}{l}\text { This work, } \\
-180^{\circ} \mathrm{C}\end{array}$ & $\begin{array}{l}\text { Results from references, } \\
\text { ca. }-190^{\circ} \mathrm{C}\end{array}$ & Assignment \\
\hline \multirow[t]{3}{*}{ Ice } & & 212 & & $\begin{array}{l}\text { Translatory } \\
\text { modes }^{b}\end{array}$ \\
\hline & & $\begin{array}{l}\sim 3104 \\
\sim 3150 \text { strong } \\
(3160)^{\mathrm{a}}\end{array}$ & $\begin{array}{l}\sim 3090 \pm 10 \\
{[12], \quad[19], \quad[25]-[26], \quad[28],} \\
{[32],[36]}\end{array}$ & \multirow[t]{2}{*}{$\begin{array}{l}\mathrm{OH} \\
\text { stretching }\end{array}$} \\
\hline & & $\sim 3400$ & $\begin{array}{l}3250 \pm 50 \text { broad } \\
\text { [19], [25]-[26], [32] }\end{array}$ & \\
\hline \multirow[t]{8}{*}{ Hydrohalite } & 192,230 & & & $\begin{array}{l}\text { Translatory } \\
\text { modes }^{\mathrm{b}}\end{array}$ \\
\hline & 1646 & & 1649 [25] & \multirow[b]{2}{*}{$\begin{array}{l}\mathrm{HOH} \\
\text { bending }^{c}\end{array}$} \\
\hline & 1665 & $\begin{array}{l}1665 \\
(1673)^{a}\end{array}$ & 1665 [25] & \\
\hline & 3223 & & 3209 [19], [25] & \multirow[b]{5}{*}{$\begin{array}{l}\mathrm{OH} \\
\text { stretching }^{d}\end{array}$} \\
\hline & 3296 & & & \\
\hline & 3322 & & 3326 [27] & \\
\hline & & 3406 & $\begin{array}{l}\sim 3406 \pm 6 \\
{[12], \quad[19], \quad[25]-[29], \quad[32]-} \\
{[33],[36]}\end{array}$ & \\
\hline & $\begin{array}{l}3423 \text { strong } \\
(3438)^{a}\end{array}$ & 3422 & $\begin{array}{l}\sim 3422 \pm 3 \\
{[12], \quad[19], \quad[25]-[29], \quad[32],} \\
{[36]}\end{array}$ & \\
\hline
\end{tabular}


R. W. Berg: $\quad$ Hydrohalite, Raman and safe traffic

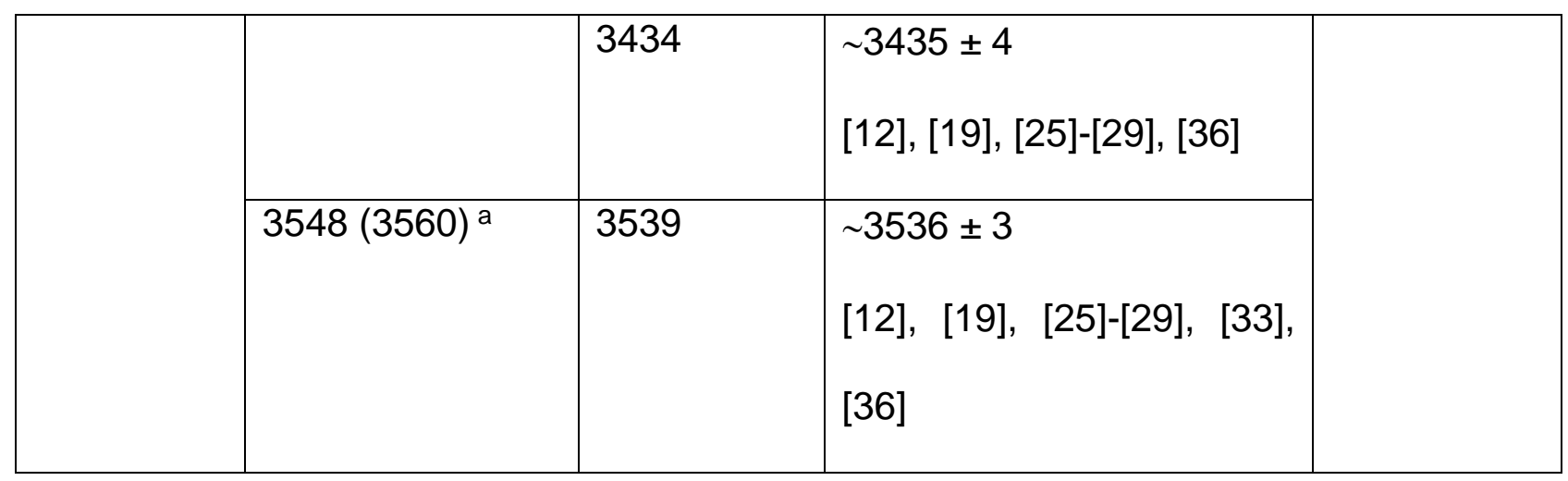

${ }^{\text {a }}$ Bands measured with the B\&WTEK i-Raman+ spectrometer are given in parantheses (not precisely calibrated).

${ }^{b}$ Low frequency translatory lattice modes in ice [46] and hydrohalite [25].

${ }^{\mathrm{c}}$ Four distinct formula units (8 water molecules) occur in the primitive monoclinic unit cell of hydrohalite [14]. It may give up to $8 \mathrm{HOH}$ bending modes that apparently add up to two bands [24].

${ }^{d}$ The 8 water molecules $\left(\mathrm{see}^{\mathrm{c}}\right.$ ) in the structure [14] give rise to $16 \mathrm{OH}$ stretching modes that form several distinct $\mathrm{OH}$ stretching bands.

\section{Alternative deicers}

Other compounds than hydrohalite are not part of the binary $\mathrm{NaCl}-\mathrm{H}_{2} \mathrm{O}$ Phase system (Figure 2) and will therefore exert their own independent freezing point depression on the ice. In practice it has been shown that the effect is active, and a number of alternative deicing agents are available, preferably cheap, harmless and non-corrosive compounds [50]-[52]. Common deicer compounds on the market are used for higway and airport pavements and comprise chlorides of magnesium, calcium and potassium $\left(\mathrm{MgCl}_{2}, \mathrm{CaCl}_{2}, \mathrm{KCl}\right)$, acetates of calcium, magnesium and potassium $\left(\mathrm{CaMg}_{2}\left(\mathrm{CH}_{3} \mathrm{COO}\right)_{6}, \mathrm{KCH}_{3} \mathrm{CO}_{2}\right)$, formates of sodium, 
R. W. Berg: $\quad$ Hydrohalite, Raman and safe traffic

potassium and calcium $\left(\mathrm{NaHCO}_{2}, \mathrm{KHCO}_{2}\right.$ and $\left.\mathrm{Ca}\left(\mathrm{HCO}_{2}\right)_{2}\right)$, urea $\left(\mathrm{CO}\left(\mathrm{NH}_{2}\right)_{2}\right)$ and various alcoholic antifreeze agents like methanol $\left(\mathrm{CH}_{3} \mathrm{OH}\right)$, ethylene glycol $\left(\mathrm{C}_{2} \mathrm{H}_{4}(\mathrm{OH})_{2}\right)$, propylene glycol $\left(\mathrm{C}_{3} \mathrm{H}_{6}(\mathrm{OH})_{2}\right)$ and glycerol $\left(\mathrm{C}_{3} \mathrm{H}_{5}(\mathrm{OH})_{3}\right)$. Some of these deicers are spread as liquids and solutions that depress the freezing point of water to quite low temperatures, are little corrosive and have low environmental impact, while being very efficient at removing the ice. Potassium acetate is such an example.

\section{Conclusions}

The traditional $\mathrm{NaCl}$ spreading procedure for de-icing of roads is sometimes ineffective, because the temperature is too cold or because slippery solid $\mathrm{NaCl} \cdot 2 \mathrm{H}_{2} \mathrm{O}$ has accidentally been formed that will resist further deicing; only ice but not hydrohalite reacts with the salt as it may be deduced from the known phase diagram of the $\mathrm{H}_{2} \mathrm{O}-\mathrm{NaCl}$ system (Figure 2).

Raman spectra of hydrohalite $\left(\mathrm{NaCl} \cdot 2 \mathrm{H}_{2} \mathrm{O}\right)$ have been reviewed and re-measured. The spectra clearly reveal that any hydrohalite formation can be detected with a rather simple portable Raman system: Hydrohalite gives a strong Raman band near $3423 \mathrm{~cm}^{-1}$ (Figure 5) differing from the strong ice band at ca. $3150 \mathrm{~cm}^{-1}$ (Figure 3). These bands can be used to differentiate between the hydrohalite and the ice phases, even though the hydrohalite spectral band positions depend somewhat on the temperature.

This means that it is rather simple to detect situations when salt spreading will not work and a better deicing procedure could be utilized, and warnings could be sent out to road users to take extra care to avoid accidents. Deicer snowplows may be designed with small laser Raman spectrometers pointing to the "ice" and discriminating between ice and hydrohalite 
R. W. Berg: $\quad$ Hydrohalite, Raman and safe traffic

while "salting" is carried out. If hydrohalite is found one could automatically shift to spreading another deicer, perhaps mixed with sand and gravel when needed (Figure 1).

\section{Acknowledgements}

The author is grateful to discussions with and help from Morten Mejlholm and Kaj Thomsen at DTU Chemical Engineering and Fragkiskos Tzirakis at DTU Center for Energy Resources Engineering (CERE), DK-2800 Kgs. Lyngby, Denmark. Bent Svanholm from Svanholm.com contributed with recording spectra with his portable B\&WTEK i-Raman Plus spectrometer system. Claus Burke Mortensen helped with the artwork.

\section{Conflict of Interest}

The author declares that there is no conflict of interest.

\section{Funding}

The Danish Agency for Science, Technology and Innovation (FTP) paid for the Raman instrumentation. A grant from the Tuborg foundation made it possible to purchase the LINKAM accessory to the DILOR Raman instrument. 
R. W. Berg: $\quad$ Hydrohalite, Raman and safe traffic

\section{References}

[1] Adams, L.H. and Gibson, R.E. (1930) The Melting Curve of Sodium Chloride Dihydrate. An Experimental Study of an Incongruent Melting at Pressures up to Twelve Thousand Atmospheres. J. Amer. Chem. Soc., 52(11): 4252-4264.

[2] Roedder, E. (1962) Studies of Fluid Inclusions I: Low temperature application of dual purpose freezing and heating stage. Econ. Geol., 57(7): 1045-1061.

[3] Roedder, E. (1963) Studies of Fluid Inclusions II, Freezing data and their interpretation. Econ. Geol., 58(2): 167-211.

[4] Cocks, F.H. and Brower, W.E. (1974) Phase Diagram Relationships in Cryobiology. Cryobiology, 11(4): 340-358.

[5] Potter II, R.W., Clynne, M.A. and Brown, D.L. (1978) Freezing point depression of aqueous sodium chloride solutions. Econ. Geol., 73(2): 284-285.

[6] Crawford, M.L. (1981) (a) Phase equilibria in aqueous fluid inclusions. MSA Short Course in Fluid Inclusions: Applications in Petrology, Hollister, L.S. and Crawford, M.L., Eds. pp. 75100. (b) Fluid Inclusions: Applications to Petrology (Hollister, L.S. and Crawford, M.L. Eds.). Min. Assoc. Canada, Short Course Handbook, Calgary, Alberta, Canada, 6: pp. 157-181.

[7] Hall, D.L., Sterner, S.M. and Bodnar, R.J. (1988) Freezing point depression of NaCl-KCl$\mathrm{H}_{2} \mathrm{O}$ solutions. Econ. Geol., 83(1): 197-202. 
R. W. Berg: $\quad$ Hydrohalite, Raman and safe traffic

[8] Light, B., Brandt, R.E. and Warren, S.G. (2009) Hydrohalite in cold sea ice: Laboratory observations of single crystals, surface accumulations, and migration rates under a temperature gradient, with application to 'Snowball Earth'. J. Geophys. Res., 114(C07018): 1-17.

[9] Muldrew, K. and McGann, L.E. (1997) Cryobiology - A Short Course (Web-based textbook). Universities of Calgary and Alberta, Alberta, Canada. Available at:

https://people.ucalgary.ca/ kmuldrew/cryo course/cryo chap6 1.html (accessed April 2017).

[10] Petersen, E.U. (1996) Phase Diagrams in Vivo. University of Utah, Salt Lake City, Utah. Available at: http://www.minsocam.org/msa/Monographs/Mngrph_03/MG003_147-158.pdf . (accessed April 2017).

[11] van den Kerkhof, A.M. and Sosa, G.M. (2012) Fluid inclusions - Petrography and genetic interpretation of fluid Inclusions.: Fluidhandout_2012_Hefei.pdf from Geowissenschaftliches Zentrum der Universität Göttiingen (Germany) and Dept. Earth and Space Sciences, Univ. Sci. and Techn. Hefei, Anhui 230026 (P.R.China), March 27-30. Available at: http://www.unigoettingen.de/de/document/download/af747f0effe56e06177bc4eef6c6c49d.pdf/Fluidhando ut_2012_Hefei.pdf\&sa=U\&ved=0ahUKEwjg-Sy4bLTAhWCjiwKHW3vD4oQFggFMAA\&client=internal-udscse\&usg=AFQjCNGET9PrAA2raEXYZJea1kkHI3ZYjA (accessed April 2017). 
R. W. Berg: $\quad$ Hydrohalite, Raman and safe traffic

[12] Valenti, P., Bodnar, R.J. and Schmidt, C. (2012) Experimental determination of $\mathrm{H}_{2} \mathrm{O}-$ $\mathrm{NaCl}$ liquidi to 25 mass $\% \mathrm{NaCl}$ and $1.4 \mathrm{GPa}$ : Application to the Jovian satellite Europa. Geochim. Cosmochim. Acta, 92(9): 117-128.

[13] Lamprecht, G. and Nuber, B. (1972) Röntgenographische Untersuchung des Hydrohalits $\mathrm{NaCl} \cdot 2 \mathrm{H}_{2} \mathrm{O}$. Neues Jb. Miner. Monatsh., pp. 325-328.

[14] Klewe, B. and Pedersen, B. (1974) The crystal structure of sodium chloride dihydrate. Acta Cryst. B, 30: 2363-2371.

[15] Craig, J.R., Light, J.F., Parker, B.C. and Mudrey Jr., M.G. (1975) Identification of hydrohalite. Antarct. J. (U.S.)., 10: 178-179.

[16] Bodnar, R.J. (1993) Revised equation and table for determining the freezing point depression of $\mathrm{H}_{2} \mathrm{O}-\mathrm{NaCl}$ solutions. Geochim. Cosmochim. Acta, 57(3): 384-683.

[17] Koop, T., Kapilashrami, A., Molina, L.T. and Molina, M.J. (2000) Phase transitions of sea-salt/water mixtures at low temperatures: Implications for ozone chemistry in the polar marine boundary layer, J. Geophys. Res., 105(D21): 26,393-26,402.

[18] Marion, G.M. and Grant., S.A. (July 1994) FREZCHEM: A Chemical-Thermodynamic Model for Aqueous Solutions at Subzero Temperatures. Special Report 94-18, U.S. Army Corps of Engineers, Cold Regions Research and Engineering Laboratory. Available at: http://oai.dtic.mil/oai/oai?verb=getRecord\&metadataPrefix=html\&identifier=ADA288456. (accessed April 2017). 
R. W. Berg: $\quad$ Hydrohalite, Raman and safe traffic

[19] Chi, G., Chu, H., Scott, R. and Chou I-M. (2014) A new method for determining fluid compositions in the $\mathrm{H}_{2} \mathrm{O}-\mathrm{NaCl}-\mathrm{CaCl}_{2}$ system with Cryogenic Raman Spectroscopy. Acta Geol. Sin-Engl., 88(4): 1169-1182.

[20] Mejlholm, M., Thomsen, K., Rasmussen, P.,Vergod, J., Knudsen, F. and Høyer H. (, 2002) Sodium Chloride Dihydrate - A Potential Cause of Slippery Accidents. Proceedings of the XIth PIARC International Winter Road Congress, Sapporo, Japan, January 28-31. 6 pp.

[21] Daniel, I. and Caracas, R. (2009) Hydrohalite: properties of a major hydrate in the $\mathrm{H}_{2} \mathrm{O}$ $\mathrm{NaCl}$ binary. Amer. Geophys. Union. Fall Meeting. Abstract \#MR23A-1677. Http://adsabs.harvard.edu/abs/2009AGUFMMR23A1677D.

[22] Rosenberg, R. (2005) Why is ice slippery? Physics Today, (12):50-55.

[23] Craig, J.R., Fortner, R.D. and Weand, B.L. (1974) Halite and Hydrohalite from Lake Bonney, Taylor Valley, Antarctica. Geology, 2(8): 389-390. doi:10.1130/0091-7613(1974)2 $<389: H A H F L B>2.0 . C O ; 2$.

[24] Davis, D.W., Lowenstern, T.K. and Spencer R.J. (1990) Melting behavior of fluid inclusions in laboratory-grown halite crystals in the systems $\mathrm{NaCl}-\mathrm{H}_{2} \mathrm{O}, \mathrm{NaCl}-\mathrm{KCl}-\mathrm{H}_{2} \mathrm{O}$, $\mathrm{NaCl}-\mathrm{MgCl}_{2}, \mathrm{NaCl}-\mathrm{CaCl}_{2}-\mathrm{H}_{2} \mathrm{O}$. Geochim. Cosmochim. Acta, 54(3): 591-601.

[25] Dubessy, J., Audeoud, D., Wilkins, R. and Kosztolanyi. C. (1982) The use of the Raman micro-probe mole in the determination of the electrolytes dissolved in the aqueous phase of fluid inclusions. Chem. Geol., 37(1-2): 137-150. 
R. W. Berg: $\quad$ Hydrohalite, Raman and safe traffic

[26] Samson, I.M. and Walker, R.T. (2000) Cryogenic Raman Spectroscopic Studies in the System NaCl-CaCl $2-\mathrm{H}_{2} \mathrm{O}$ and Implications for Low-Temperature Phase Behavior in Aqueous Fluid Inclusions. Can. Mineral., 38(1): 35-43.

[27] Bakker, R.J. (2004) Raman spectra of fluid and crystal mixtures in the systems $\mathrm{H}_{2} \mathrm{O}$, $\mathrm{H}_{2} \mathrm{O}-\mathrm{NaCl}$ and $\mathrm{H}_{2} \mathrm{O}-\mathrm{MgCl}_{2}$ at low temperatures: applications to fluid-inclusion research. Can. Mineral., 42(5): 1283-1314.

[28] Ni, P., Ding, J. and Rao, B. (2006) In situ cryogenic Raman spectroscopic studies on the synthetic fluid inclusions in the systems $\mathrm{H}_{2} \mathrm{O}$ and $\mathrm{NaCl}-\mathrm{H}_{2} \mathrm{O}$. Chinese Sci. Bull., 51(1): 108-114.

[29] Gasparrini, M., Bakker, R.J. and Bechstädt, T. (2006) Characterization of Dolomitizing Fluids in the Carboniferous of the Cantabrian Zone (NW Spain): A Fluid-Inclusion Study with Cryo-Raman Spectroscopy. J. Sedimentary Res., 76(12): 1304-1322. doi: 10.2110/jsr.2006.106.

[30] Lapponi, F., Bakker, R.J. and Bechstaedt, T. (2007) Low temperature behaviour of natural saline fluid inclusions in saddle dolomite (Paleozoic, NW Spain). Terra Nova, 19(6): 440-444. doi: 10.1111/j.1365-3121.2007.00769.x.

[31] Derome, D., Cathelineau, M., Fabre, C., Boiron, M.-C., Banks, D., Lhomme, T. and Cuney, M. (2007) Paleo-fluid composition determined from individual fluid inclusions by Raman and LIBS: Application to mid-proterozoic evaporitic Na-Ca brines (Alligator Rivers Uranium Field, northern territories Australia). Chem. Geol., 237(3-4): 240-254. 
R. W. Berg: $\quad$ Hydrohalite, Raman and safe traffic

[32] Baumgartner, M. and Bakker, R.J. (2010) Raman spectra of ice and salt hydrates in synthetic fluid inclusions. Chem. Geol., 275(1-2): 58-66.

[33] Wise, M.E., Baustian, K.J., Koop, T., Freedman, M.A., Jensen, E.J. and Tolbert, M.A. (2012) Depositional ice nucleation onto crystalline hydrated $\mathrm{NaCl}$ particles: $\mathrm{A}$ new mechanism for ice formation in the troposphere. Atmos. Chem. Phys.,12(2): 1121-1134. doi:10.5194/acp-12-1121-2012.

[34] Wagner, R. and Möhler, O. (2013) Heterogeneous ice nucleation ability of crystalline sodium chloride dihydrate particles. J. Geol. Res., 118(10): 4610-4622. doi:10.1002/jgrd.50325.

[35] Journaux, B., Daniel, I., Caracas, R., Montagnac, G. and Cardon, H. (2013) Influence of $\mathrm{NaCl}$ on ice $\mathrm{VI}$ and ice VII melting curves up to $6 \mathrm{GPa}$, implications for large icy moons. Icarus (Elsevier), 226 (1): 355-363. doi:10.1016/j.icarus.2013.05.039.

[36] Vu, T.H., Hodyss, R., Choukroun, M. and Johnson, P.V. (2016) Chemistry of Frozen Sodium-Magnesium-Sulfate-Chloride Brines: Implications for Surface Expression of Europa's Ocean Composition. Astrophys. J. Lett., 816(2): L26 (6 pp.). doi:10.3847/20418205/816/2/L26.

[37] Dong, J., Malsam, J., Bischof, J.C., Hubel, A. and Aksan, A. (2010) Spatial Distribution of the State of Water in Frozen Mammalian Cells. Biophys. J., 99(8): 2453-2459. 
R. W. Berg: $\quad$ Hydrohalite, Raman and safe traffic

[38] Kreiner-Møller, A., Stracke, F. and Zimmermann, H. (2013) Confocal Raman microscopy as a non-invasive tool to investigate the phase composition of frozen complex cryopreservation media. CryoLetters, 34(3): 248-254.

[39] Kreiner-Møller, A., Stracke, F. and Zimmermann, H. (2014) Hydrohalite spatial distribution in frozen cell cultures measured using confocal Raman microscopy. Cryobiology, 69(1): 41-47.

[40] Okotrub, K.A. and Surovtsev, N.V. (2013) Raman scattering evidence of hydrohalite formation on frozen yeast cells. Cryobiology, 66(1): 47-51.

[41] Berg, R.W., Ferré, I.M. and Schäffer, S.J.C. (2006) Raman spectroscopy evidence of 1:1:1 complex formation during dissolution of $\mathrm{WO}_{3}$ in a melt of $\mathrm{K}_{2} \mathrm{~S}_{2} \mathrm{O}_{7}: \mathrm{K}_{2} \mathrm{SO}_{4}$. Vibrat. Spectrosc., 42(2): 346-352.

[42] Liu, C. and Berg, R.W. (2012) Determining the Spectral Resolution of a Charge-Coupled Device (CCD) Raman Instrument. Appl. Spectrosc., 66(9): 1034-1043.

[43] Liu, C. and Berg, R.W. (2013) Nonlinearity in Intensity versus Concentration Dependence for the Deep UV Resonance Raman Spectra of Toluene and Heptane. Appl. Spectrosc. Rev., 48(5): 425-437.

[44] Datasheets on the BWTEK portable i-Raman system are available at: http://www.svanholm.com/_bwtek_portable-iraman_plus.htm http://www.svanholm.com/Download/BW\%20tek/Datasheet_i-Raman_Plus.pdf (accessed April 2017).

[45] Whalley, E. (1973) Lattice Dynamics of Ice. In Physics and Chemistry of Ice, Whalley, E., Jones, S.J. and Gold, L.W., Eds. Royal Society of Canada, Ottawa. pp. 73-81. 
R. W. Berg: $\quad$ Hydrohalite, Raman and safe traffic

[46] Wong, P.T.T., Klug, D.D. and Whalley, E. (1973) The Raman spectrum of the translational Lattice vibrations of Ice $\ln$. In Physics and Chemistry of Ice, Whalley, E., Jones, S.J. and Gold, L.W., Eds. Royal Society of Canada, Ottawa. pp. 87-92.

[47] Whalley, E. (1977) A detailed assignment of the O-H stretching bands of ice I. Can. J. Chem. 55(19): 3429-3441.

[48] Sivikumar, T.C., Chew, H.A.M. and Johari, G.P. (1978) Effect of pressure on the Raman spectrum of ice. Nature, 275:524-525.

[49] Dolenko, T.A., Churina, I.V., Fadeev, V.V. and Glushkov, S.M. (2000) Valence band of liquid water Raman scattering: Some peculiarities and applications in the diagnostics of water media. J. Raman Spectrosc., 31(8-9): 863-870.

[50] Fischel, M. (2001) Evaluation of Selected Deicers Based on a Review of the Literature, SeaCrest Group Final Technical Report No. CDOT-DTD-R-2001-15, October 2001, Colorado Department of Transportation, pp. 1-273.

[51] Hellstén, P.P., Salminen, J.M., Jørgensen, K.S., Nystén, T.H. (2005) Use of potassium formate in road winter deicing can reduce groundwater deterioration. Environ. Sci. Technol., 39(13): 5095-5100.

[52] Cunningham, M.A., Snyder, E., Yonkin, D., Ross, M. and Elsen, T. (2008) Accumulation of deicing salts in soils in an urban environment. Urban Ecosystems, 11: 17-31. 


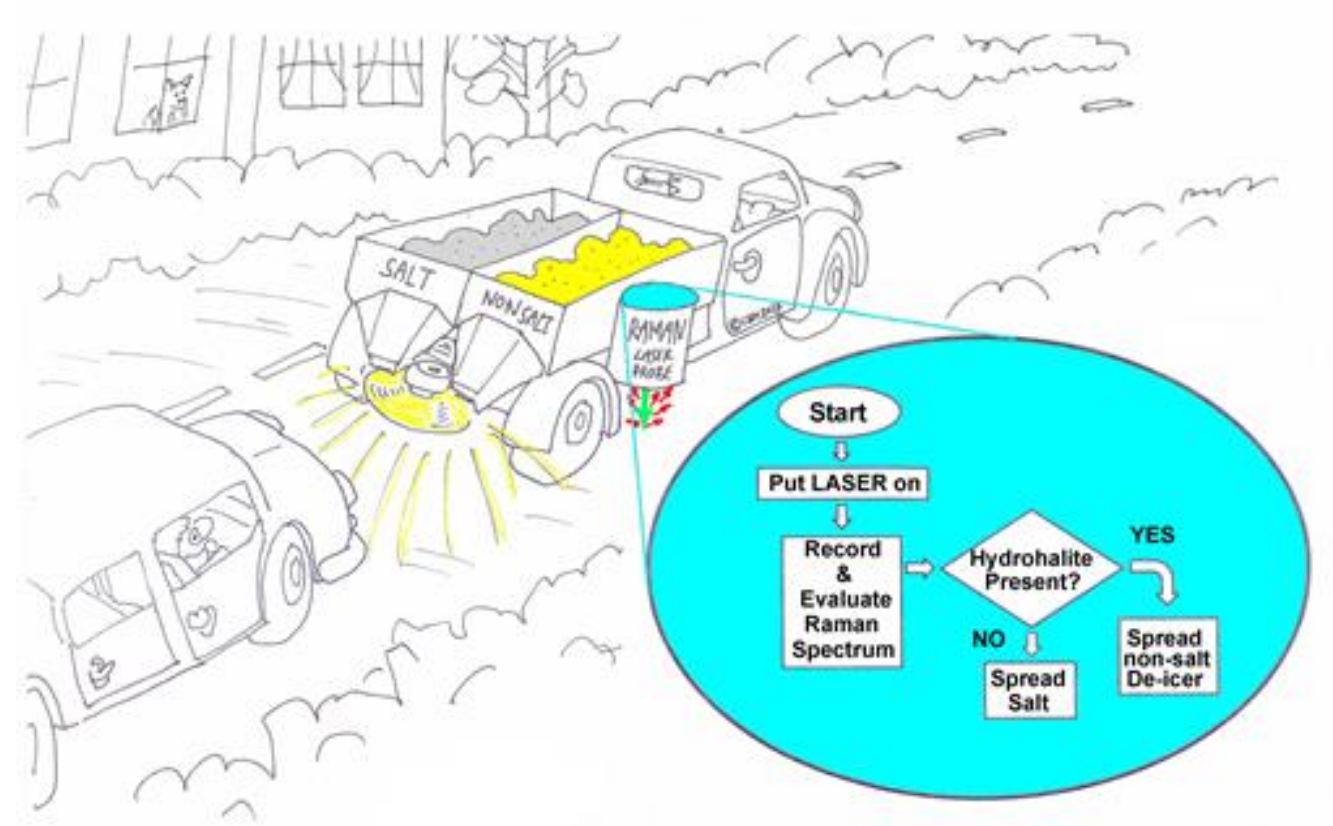

Figure 1. Experience has shown that roads may sometimes remain slippery even after salting. In this review we argue that a reason might be related to unnoticed formation of hydrohalite $\left(\mathrm{NaCl} \cdot 2 \mathrm{H}_{2} \mathrm{O}\right)$ that does not melt after spreading of $\mathrm{NaCl}$ (salt). In this work, the formation and detection of hydrohalite is discussed and studied. We conclude that it is possible to detect hydrohalite on frosted salty roads with a rather simple portable Raman spectrometer. As shown in this drawing a future possibility to avoid accidents could be to detect and react on the hydrohalite presence by spreading an alternative non-salt deicer. 


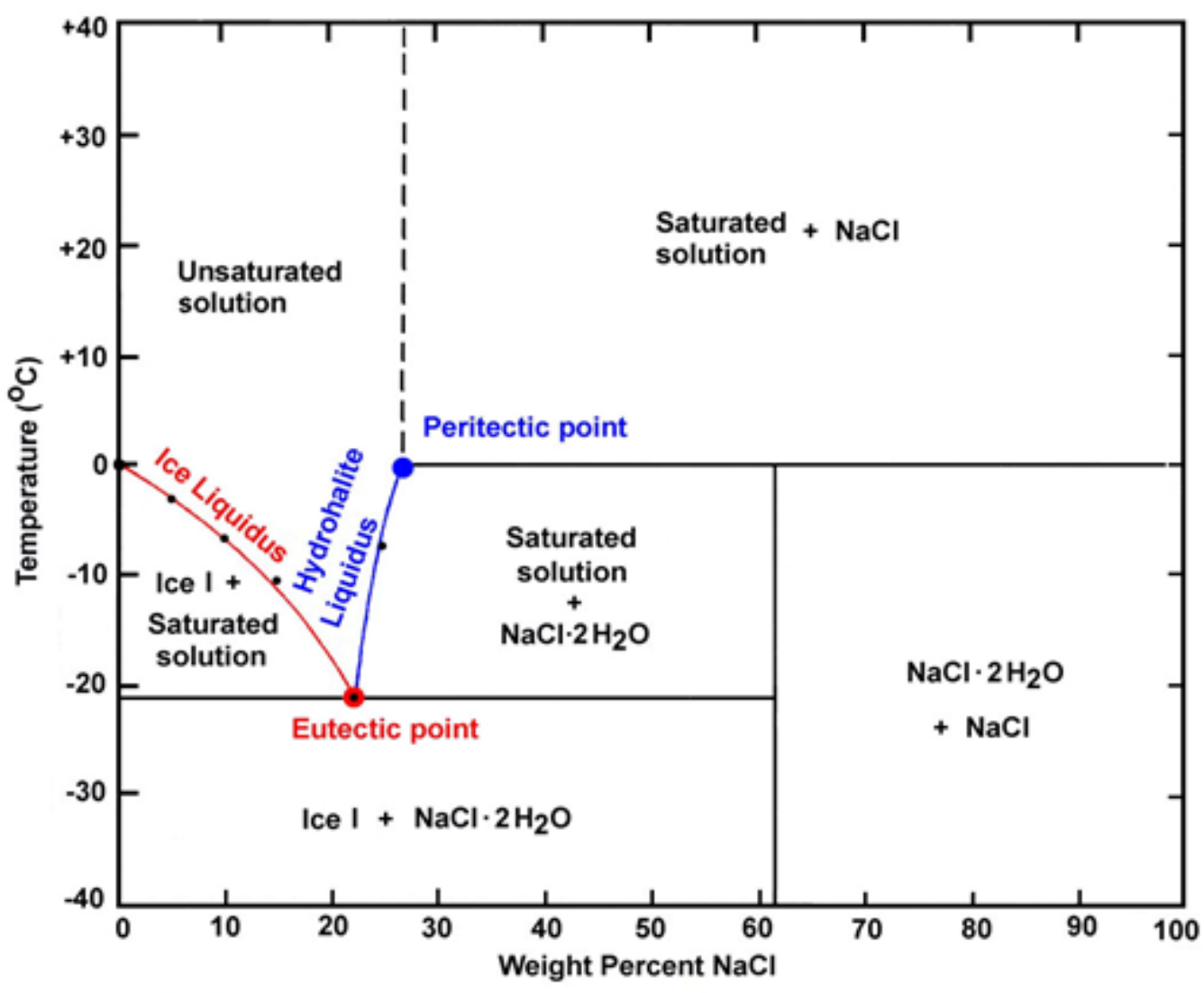

Figure 2. Phase diagram of the binary $\mathrm{NaCl}-\mathrm{H}_{2} \mathrm{O}$ system, redrawn from data in e.g. [1]-[11] and with black points from [12]. The ice liquidus (red curve) has been carefully expressed by equations giving the freezing point versus the salt concentration [5],[7],[16],[18]. It should be noted that certain diagrams in the literature contain errors, e.g. [4], [9]-[10]. 


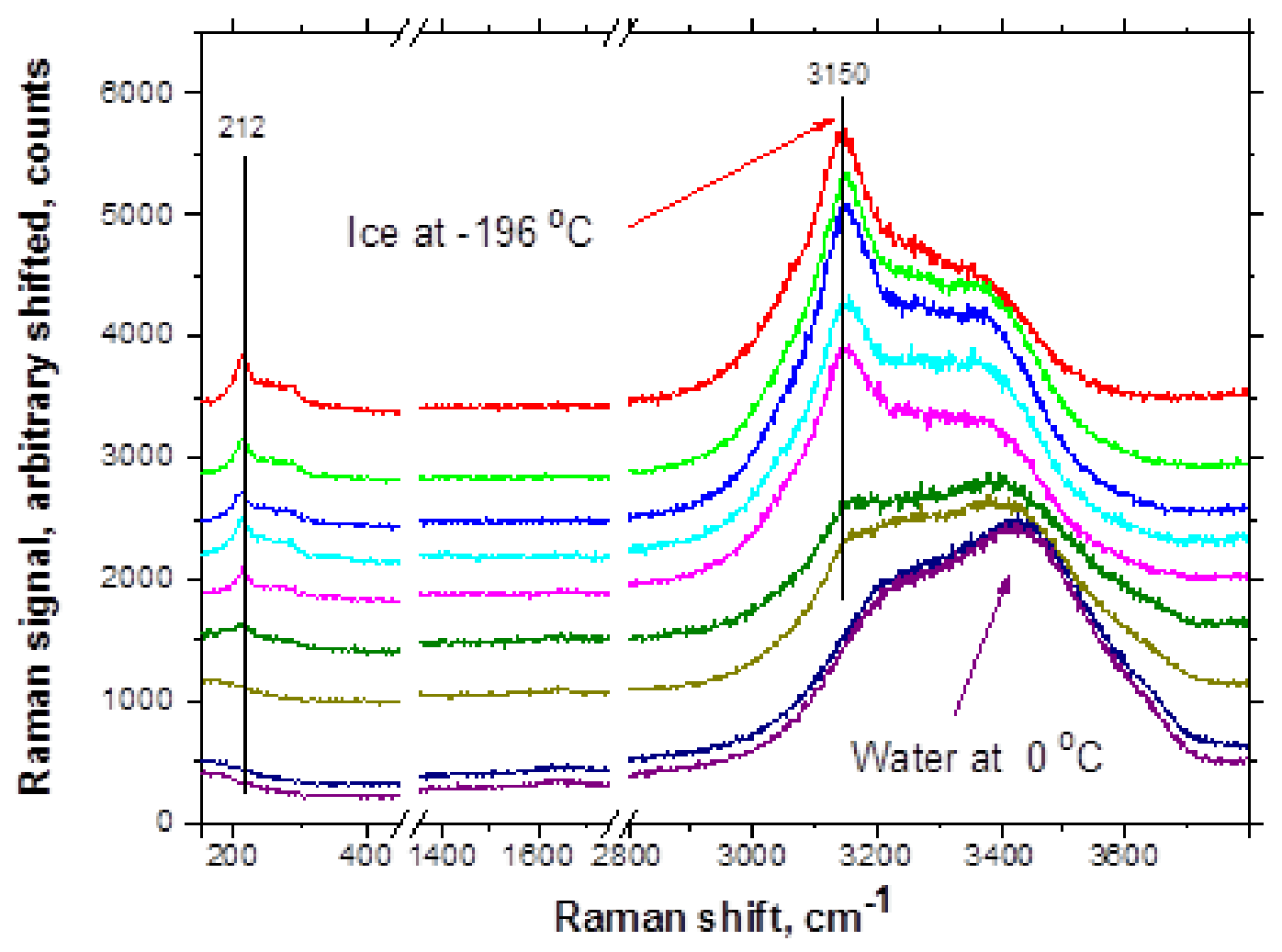

Figure 3. Raman spectra of water and ice obtained with $488 \mathrm{~nm}$ blue light ( $200 \mathrm{~mW})$ on the Renishaw spectrometer with a $\sim 65 \mu \mathrm{m}$ slit. The results of cooling are shown above the water spectrum. 
R. W. Berg: $\quad$ Hydrohalite, Raman and safe traffic

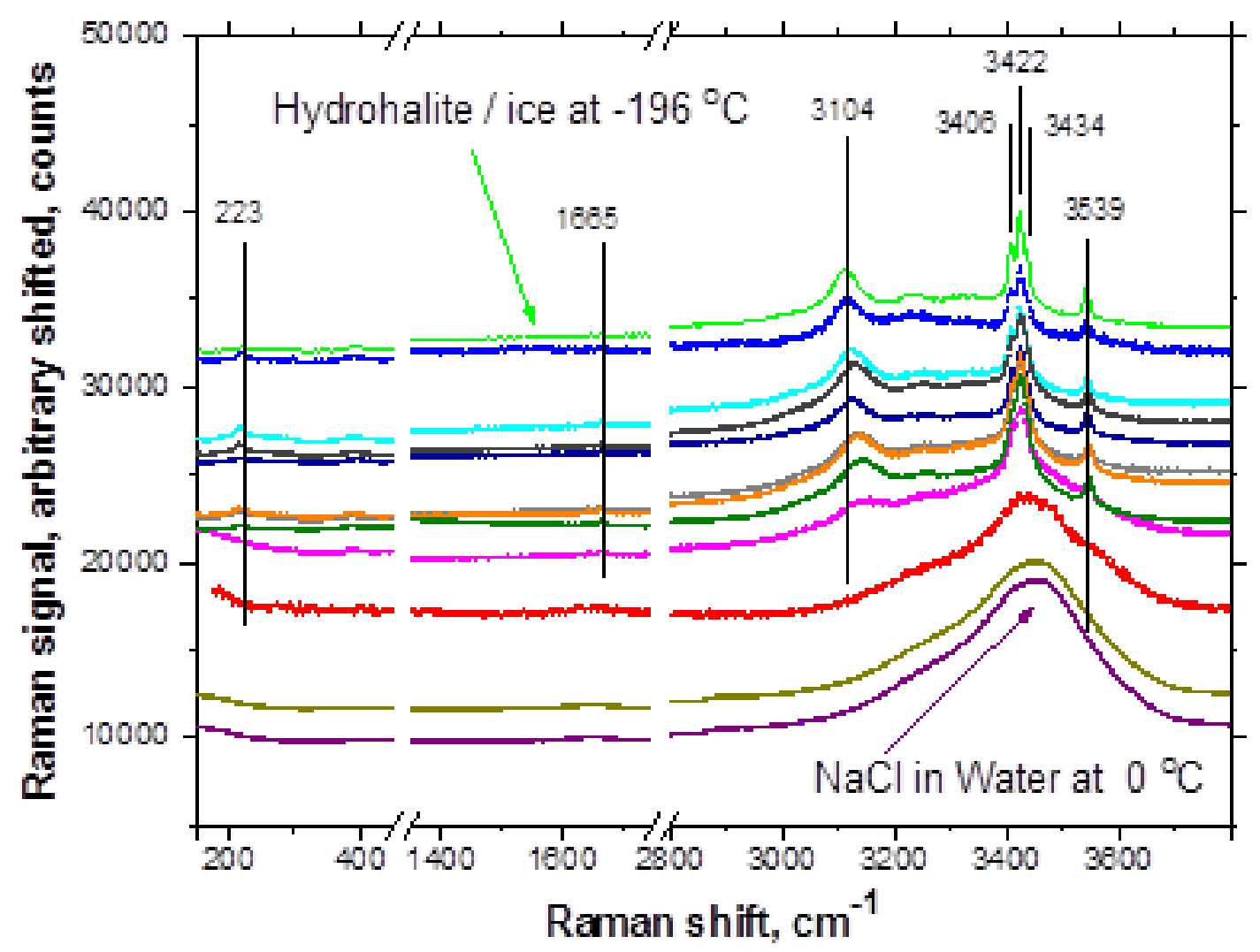

Figure 4. Raman spectra of saturated brine ( $\mathrm{NaCl}$ in water) excited with $488 \mathrm{~nm}$ blue light ( $\sim 200 \mathrm{~mW})$ on the Renishaw spectrometer with a $\sim 65 \mu \mathrm{m}$ slit. Above the two brine spectra the formation of mixtures of hydrohalite and ice can be seen versus progressive cooling. 


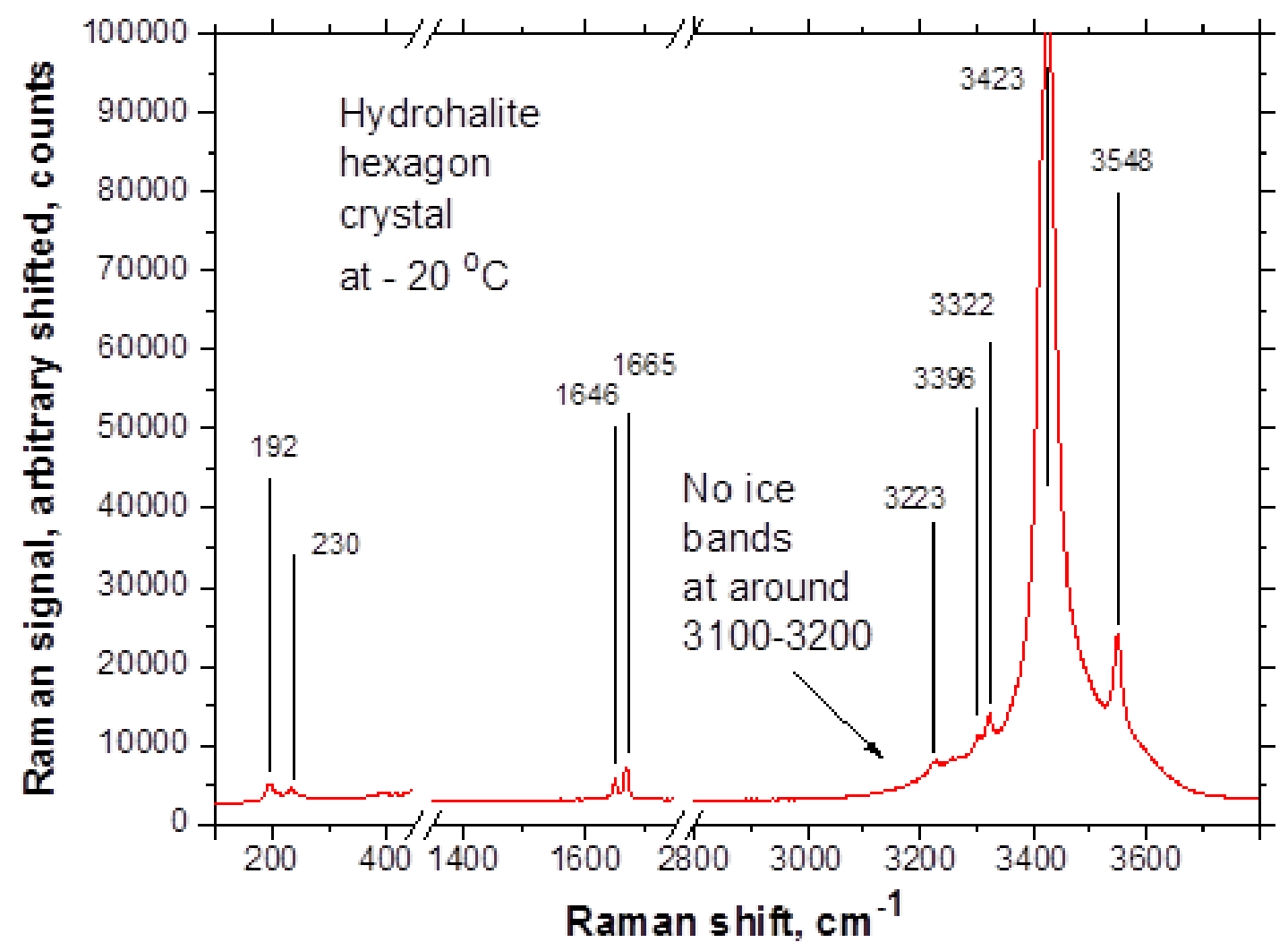

Figure 5. Raman spectrum of hydrohalite excited with $515.5 \mathrm{~nm}$ green light on a DILOR-XY spectrometer with a $300 \mathrm{~nm}$ slit. The crystal of hexagon plate shape was grown in a deep freezer and transferred to a LINKAM HFS91/TP93 stage filled with dry nitrogen and tempered at $\sim 20^{\circ} \mathrm{C}$. Note the absence of bands due to ice. 
R. W. Berg: $\quad$ Hydrohalite, Raman and safe traffic

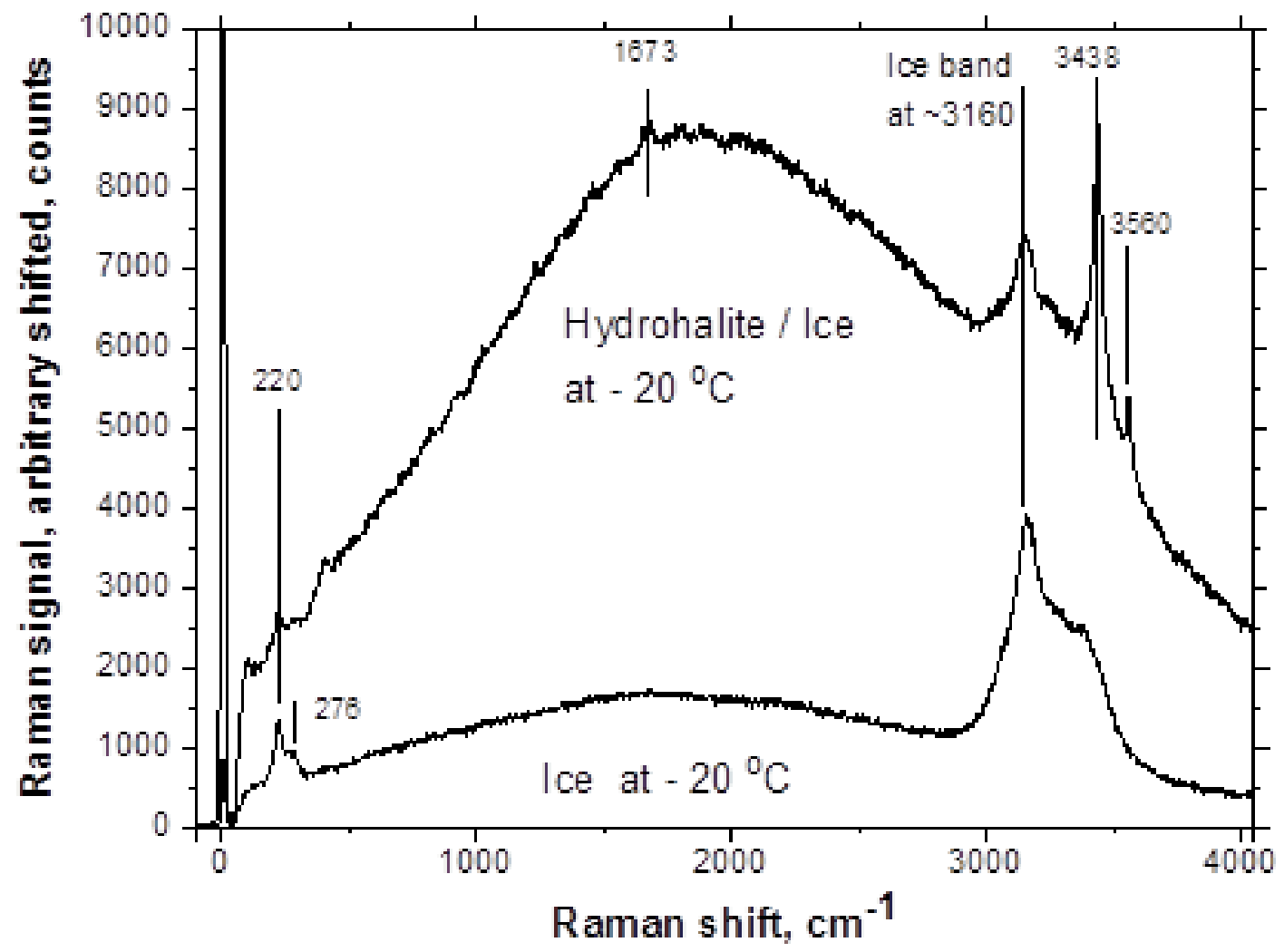

Figure 6. Raman spectra of hydrohalite and ice excited with $532 \mathrm{~nm}$ green light and recorded through fiber optic cables and a measuring head on a portable B\&WTEK i-Raman Plus spectrometer [44]. The samples were grown in a deep freezer, tempered at $\sim 26{ }^{\circ} \mathrm{C}$. Bands indicative for hydrohalite are seen at 3438 and $3560 \mathrm{~cm}^{-1}$ (not precisely calibrated). 